\title{
ANALISIS SISTEM AKUNTANSI PENGELUARAN KAS PADA BADAN PERENCANAAN PENELITIAN DAN PENGEMBANGAN DAERAH KOTA MANADO
}

\author{
Clarissa Bellinda Rondonuwu ${ }^{1}$, Ventje Ilat ${ }^{2}$, Treesje Runtu ${ }^{3}$ \\ 1, 2, 3 Jurusan Akuntansi, Fakultas Ekonomi dan Bisnis, Universitas Sam Ratulangi, Jl. Kampus Bahu, Manado, \\ 95115, Indonesia \\ E-mail: clarissarondonuwu@gmail.com
}

\begin{abstract}
A good cash disbursement system in government agencies has several important benefits, among others, is to make effective the costs incurred by government agencies, prevent the occurrence of misuse, misappropriation, and embezzlement of cash and help agencies in predicting the determination of the amount of cash budget that should be available for activities in the coming period. This study, aims to determine the cash disbursement system based on Domestic Regulation No. 21 of 2011. The research was conducted at the Manado Regional Research and Development Planning Board. In this study the source of the data used is primary data obtained directly through interviews and the informant used was the chairman of the financial sub-section. The results obtained showed that the accounting information system regarding the cash disbursement system was good, even in its implementation it was in accordance with Domestic Regulation No. 21 of 2011.
\end{abstract}

Keywords: cash disbursement; system; accounting; government

\section{PENDAHULUAN}

Pengelolaan keuangan daerah pemerintah mengacu pada peraturan Departemen Dalam Negeri yaitu Peraturan Menteri Dalam Negeri (Permendagri) Nomor 13 tahun 2006 tentang pedoman pengelolaan keuangan daerah. Peraturan ini dijabarkan lebih lanjut dalam Surat Edaran Nomor SE.900/316/BAKD yang mencakup pedoman sistem dan prosedur penatausahaan dan akuntansi, pelaporan dan pertanggungjawaban keuangan daerah, yang kemudian peraturan tersebut mengalami dua kali perubahan yaitu perubahan pertama Peraturan Menteri Dalam Negeri Nomor 59 Tahun 2007 dan perubahan kedua yaitu Peraturan Pemerintah Dalam Negeri Nomor 21 Tahun 2011. Permendagri tersebut menjelaskan sistem dan prosedur keuangan daerah beserta contoh-contoh formulir yang bisa digunakan oleh pemerintah daerah dimana penyajian laporan keuangan dalam sistem dan prosedur keuangan daerah ini telah sesuai dengan Peraturan Pemerintah Nomor 24 Tahun 2005 tentang Standar Akuntansi Pemerintahan (SAP) sebagai acuan dalam penyajian laporan keuangan pemerintah.

Salah satu sistem dan prosedur keuangan daerah adalah sistem pengeluaran kas adalah serangkaian proses pengeluaran kas, baik manual maupun terkomputerisasi, yang dimulai dari pencatatan, penggolongan, dan peringkasan transaksi dan atau kejadian keuangan yang sampai pada pelaporan keuangan. Sistem pengeluaran kas pada suatu lembaga pemerintah daerah sangat penting karena kas adalah aset yang paling mudah berubah dibandingkan aset lain, sehingga kas merupakan alat pembayaran yang mudah digunakan karena selalu tersedia untuk memudahkan jalannya operasional dari suatu lembaga/instansi pemerintah daerah.

Peraturan Pemerintah Nomor 12 tahun 2019 pasal 66 angka 2 menyatakan bahwa pengguna anggaran/kuasa pengguna anggaran diberikan uang persediaan demi terciptanya kelancaran tugas SKPD. Permasalahan yang terjadi yaitu terhambatnya pencairan dana UP/GU/TU/LS dikarenakan surat pengajuan pencairan dana ditolak, yang menyebabkan surat 
perintah pencairan dana atau SP2D tidak dapat diterbitkan. Hal ini akan menghambat tugas/pekerjaan dari instansi yang bersangkutan karena harus mengulang pengajuan sesuai dengan prosedur dan belum mendapatkan dana yang diajukan (masih harus diperbaiki/dimengerti). Sistem dan prosedur akuntansi pengeluaran kas sangatlah penting diterapkan di suatu instansi pemerintah daerah sesuai dengan peraturan yang berlaku karena bertujuan untuk mengetahui efektivitas sistem dan prosedur yang dijalankan dan untuk memudahkan dalam proses pengeluaran kas.

\section{TINJAUAN PUSTAKA}

Menurut Harrison et al. (2012:3) pengertian akuntansi merupakan suatu sistem informasi, yang mengukur aktivitas bisnis, memproses data menjadi laporan dan mengkomunikasikan hasilnya kepada pengambil keputusan yang akan membuat keputusan dan dapat mempengaruhi aktivitas bisnis. Menurut Pontoh (2013:1), akuntansi pada umumnya sering disebut sebagai bahasa bisnis. Akuntansi pada dasarnya akan menghasilkan informasi dari sebuah sistem akuntansi yang ada di dalam sebuah entitas atau organisasi bisnis yang disebut dengan informasi akuntansi yang akan dimanfaatkan oleh pengguna seperti masyarakat umum dan masyarakat intelektual dan para pengambil keputusan bisnis dalam organisasi. Menurut Sujarweni (2015:1), akuntansi adalah suatu aktivitas jasa yang terdiri dari mencatat, mengklasifikasikan, dan melaporkan kejadian atau transaksi ekonomi yang akhirnya akan menghasilkan suatu informasi keuangan yang akan dibutuhkan oleh pihak-pihak tertentu untuk pengambilan keputusan.

Sistem adalah rangkaian dari dua atau lebih komponen-komponen yang saling berhubungan, yang berinteraksi untuk mencapai suatu tujuan. Sebagian besar sistem terdiri dari subsistem yang lebih kecil yang mendukung sistem yang lebih besar (Romney dan Steinbart, 2015:3). Sistem merupakan suatu bentuk integrasi antara satu komponen dengan komponen lain karena sistem memiliki sasaran yang berbeda untuk setiap kasus yang terjadi dalam sistem tersebut (Sutabri, 2012:22). Sistem informasi adalah cara-cara yang diorganisir untuk mengumpulkan, memasukkan, dan mengolah serta menyimpan data, dan cara-cara yang diorganisasi untuk menyimpan, mengelola, mengendalikan, dan melaporkan informasi sedemikian rupa sehingga sebuah organisasi dapat mencapai tujuan yang telah ditetapkan (Krismiaji, 2015:15).

Pengertian dari sistem akuntansi pemerintahan daerah dijelaskan pada Peraturan Menteri Dalam Negeri Nomor 21 tahun 2011 pasal 232 angka 3 yaitu sistem akuntansi pemerintahan daerah adalah serangkaian prosedur yang dimulai dari proses pengumpulan data, pencatatan, pengikhtisaran, sampai dengan pelaporan keuangan dalam rangka pertanggungjawaban pelaksanaan APBD yang dapat dilakukan secara manual maupun menggunakan aplikasi komputer. Sistem akuntansi pemerintahan daerah sekurang-kurangnya meliputi: prosedur akuntansi penerimaan kas, prosedur akuntansi pengeluaran kas, prosedur akuntansi aset tetap/ barang milik daerah dan prosedur akuntansi selain kas. Hal ini dijelaskan pada pasal 233 angka 1.

Menurut Chandra dan Adriana (2015:2), sistem informasi akuntansi merupakan sistem yang menyediakan informasi akuntansi dan keuangan beserta informasi lainnya yang diperoleh dari proses rutin transaksi akuntansi. Menurut Susanto (2017:80), sistem informasi akuntansi dapat didefinisikan sebagai kumpulan (integrasi) dari sub-sub sistem/komponen baik fisik maupun nonfisik yang saling berhubungan dan bekerjasama satu sama lain secara harmonis untuk mengolah data transaksi yang berkaitan dengan masalah keuangan menjadi informasi keuangan. Mulyadi (2016:15) menyatakan bahwa sistem informasi akuntansi memiliki empat tujuan dalam penyusunannya, yaitu : (a) untuk menyediakan informasi bagi pengelolaan kegiatan usaha; (b) untuk memperbaiki informasi yang dihasilkan oleh sistem yang sudah ada, baik mengenai mutu, ketepatan penyajian maupun struktur informasinya; (c) 
untuk memperbaiki pengendalian akuntansi dan pengecekan intern, yaitu untuk memperbaiki tingkat keandalan (reliability) informasi akuntansi dan untuk menyediakan catatan lengkap mengenai pertanggungjawaban dan perlindungan kekayaan perusahaan; dan (d) untuk mengurangi biaya klerikal dalam penyelenggaraan catatan akuntansi. Karakteristik dan tujuan sistem akuntansi berkaitan dengan kegiatan pengelolaan data transaksi keuangan dan non keuangan menjadi informasi yang bermanfaat guna memenuhi kebutuhan pemakainya (accounting information users).

Tenda et al. (2015) menunjukkan bahwa prosedur pelaksanaan sistem informasi akuntansi pengeluaran kas sudah sesuai dengan Permendagri Nomor 13 tahun 2006. Wonggo et al. (2017) dalam menganalisis sistem penatausahaan belanja langsung menunjukkan bahwa implementasi Pemerintah Kabupaten Minahasa Selatan sudah sesuai dengan peraturan yang berlaku hal ini berpatokan pada Peraturan Menteri Dalam Negeri Nomor 21 tahun 2011 dan sistem penatausahaan belanja langsung telah memadai. Horman et al. (2018) menunjukkan bahwa dalam pelaksanaan sistem dan prosedur penatausahaan pengeluaran kas di kantor Kecamatan Malalayang Kota Manado menunjukkan bahwa penerapan Permendagri Nomor 59 tahun 2007 pada SKPKD pemerintah Kota Manado telah sesuai. Ointu dan Budiarso (2016) menunjukkan bahwa pelaksanaan sistem dan prosedur pengeluaran kas uang persediaan pada Dinas Pendapatan Pengelolaan Keuangan dan Aset Daerah Kabupaten Bolaang Mongondow Selatan belum dilaksanakan secara optimal terkait dokumen yang disyaratkan.

\section{METODE PENELITIAN}

Penelitian ini menggunakan jenis deskriptif kualitatif yaitu dengan mendeskripsikan data sesuai pengamatan, dan menjelaskan data mengenai sistem dan prosedur pengeluaran kas dengan kalimat penjelasan secara kualitatif. Objek penelitian dilaksanakan pada Badan Perencanaan Penelitian dan Pengembangan Daerah Kota Manado yang beralamat di Jl. Balai Kota No. 1 Manado. Jenis data yang digunakan yaitu data kualitatif berupa gambaran umum Badan Perencanaan Penelitian dan Pengembangan Daerah Kota Manado dan hasil wawancara mengenai sistem dan prosedur pengeluaran kas pada Badan Perencanaan Penelitian dan Pengembangan Daerah Kota Manado. Sumber data yang digunakan adalah data primer, yaitu data diperoleh langsung dari Badan Perencanaan Penelitian dan Pengembangan Daerah Kota Manado. Metode pengumpulan data yang dilakukan adalah dokumentasi dan wawancara.

\section{HASIL PENELITIAN DAN PEMBAHASAN}

\subsection{Hasil penelitian}

Berdasarkan hasil wawancara dengan Kepala Sub Bagian Keuangan mengenai sistem dan prosedur pengeluaran kas yang ada pada Badan Perencanaan Penelitian dan Pengembangan Daerah Kota Manado, maka hasil penelitian yaitu sebagai berikut:

1. Prosedur pembuatan Surat Penyediaan Dana (SPD). Syarat untuk diterbitkannya SPD, Bendahara Pengeluaran Badan Perencanaan Penelitian dan Pengembangan Daerah Kota Manado membuat surat permohonan penerbitan SPD dan ditujukan kepada Bendahara Umum Daerah (BUD). Surat permohonan penerbitan SPD dibuat oleh Bendahara Pengeluaran harus sesuai dengan Dokumen Pelaksanaan Anggaran Satuan Kerja Perangkat Daerah (DPA-SKPD) dan anggaran kas yang berisikan rekening anggaran belanja langsung dan tidak langsung. Pengguna anggaran menandatangani surat permohonan penerbitan SPD tersebut. Kemudian, Badan Pengelolaan Keuangan dan Aset Daerah Kota Manado yang akan menerbitkan SPD.

2. Prosedur pembuatan Surat Permintaan Pembayaran (SPP). Pejabat Pelaksana Teknis Kegiatan SKPD (PPTK-SKPD) mengumpulkan dan mempersiapkan dokumen yang diperlukan dalam proses pengajuan SPP-GU/TU/UP/LS. Dokumen tersebut berupa 
dokumen SPD, buku register SPP, bukti-bukti transaksi belanja, nota, kuitansi, faktur, berita acara penerimaan dan berita acara pembayaran. Selanjutnya PPTK menyerahkan dokumen tersebut kepada Bendahara Pengeluaran untuk dibuat SPP. Bendahara Pengeluaran membuat SPP, dalam hal ini Bendahara Pengeluaran menyusun dokumen SPP berupa; Uang Persediaan (UP), Ganti Uang (GU), Tambah Uang (TU), dan Langsung (LS). Setelah SPP dibuat, SPP beserta lampirannya diserahkan ke pejabat penatausahaan/penatalaksana keuangan (Kasubag Keuangan) untuk diteruskan ke Kepala Badan Perencanaan Penelitian dan Pengembangan Daerah Kota Manado sebagai pengguna anggaran lalu dibuat SPM.

3. Prosedur Pembuatan Surat Perintah Membayar (SPM). Pejabat Penatausahaan Keuangan SKPD (PPK-SKPD) memeriksa kelengkapan dokumen SPP-UP/GU/TU/LS yang dilampirkan. Kelengkapan dokumen tersebut mengacu kepada daftar dokumen yang telah dipersyaratkan. Selanjutnya adalah melihat kesesuaian dengan DPA-SKPD yang terkait serta batasan jumlah dalam SPD yang terkait. Apabila telah dinyatakan lengkap, maka PPK-SKPD akan membuat rancangan SPM-UP/GU/TU/LS. Rancangan SPMUP/GU/TU/LS ini dibuat empat rangkap sesuai dengan rangkap SPP-UP/GU/TU/LS untuk ditandatangani oleh pengguna anggaran/kuasa pengguna anggaran. Penerbitan SPMUP/GU/TU/LS paling lambat 2 hari kerja sejak SPP-UP/GU/TU/LS diterima.

4. Prosedur Penerbitan Surat Perintah Pencairan Dana (SP2D). Pengguna Anggaran menyerahkan dokumen SPP, SPM, SPJ kepada kuasa BUD, kuasa BUD kemudian meneliti kelengkapan SPM yang diajukan. Apabila dokumen SPM-UP/GU/TU/LS dinyatakan lengkap, BUD menerbitkan SP2D paling lambat 2 hari kerja sejak diterimanya pengajuan SPM. Kelengkapan dokumen untuk penerbitan SP2D-UP/GU/TU/LS yaitu, surat pengesahan SPJ Bendahara Pengeluaran periode sebelumnya, ringkasan pengeluaran perincian objek disertai bukti pengeluaran yang sah dan bukti penyetoran. SP2D diserahkan kepada bank dan Pengguna Anggaran. Bendahara SKPD sendiri harus mencatat SP2D dan Nota Debet (dari bank) pada dokumen penatausahaan, yang terdiri dari buku kas penerimaan, buku kas pengeluaran. Pengguna anggaran menyerahkan SP2D kepada Bendahara Pengeluaran kemudian Bendahara Pengeluaran mencatat SP2D pada dokumen penatausahaan, yang terdiri dari buku pengeluaran, buku pembantu simpanan bank, buku pembantu pajak, buku pembantu panjaran, dan buku rekapitulasi pengeluaran perincian objek.

5. Prosedur Pembuatan Surat Pertanggungjawaban (SPJ). Bendahara membuat pertanggungjawaban administrasi yang disampaikan kepada pengguna anggaran paling lambat 10 bulan berikutnya. Pertanggungjawaban administrastif tersebut berupa Surat Pertanggungjawaban (SPJ) yang menggambarkan jumlah anggaran, realisasi dan sisa pagu anggaran baik secara kumulatif maupun per kegiatan. SPJ ini merupakan penggabungan dengan SPJ Bendahara Pengeluaran Pembantu. Pertanggungjawaban administrasi berupa SPJ dilampiri dengan buku kas umum, laporan penutupan kas dan SPJ Bendahara Pengeluaran dan Bendahara Pengeluaran Pembantu. Pertanggungjawaban administrasi pada bulan terakhir tahun anggaran disampaikan paling lambat hari kerja terakhir bulan tersebut. Pertanggungjawaban tersebut harus dilampiri bukti setoran sisa uang persediaan. Langkah-langkah dalam membuat dan menyampaikan SPJ Bendahara Pengeluaran adalah sebagai berikut: (a) Bendahara Pengeluaran menyiapkan laporan penutupan kas; (b) Bendahara Pengeluaran melakukan rekapitulasi jumlah-jumlah belanja dan item terkait lainnya berdasarkan Buku Kas Umum (BKU) dan Buku Pembantu BKU lainnya serta khususnya Buku Pembantu Rincian Obyek untuk mendapatkan nilai belanja per rincian obyek; (c) Bendahara Pengeluaran menggabungkan hasil rekapitulasi tersebut dengan hasil yang ada di SPJ Bendahara Pengeluaran Pembantu; (d) berdasarkan rekapitulasi dan penggabungan itu, Bendahara Pengeluaran membuat SPJ atas pengelolaan uang yang 
menjadi tanggungjawab; (e) dokumen SPJ beserta BKU, laporan penutupan kas dan SPJ Bendahara Pengeluaran Pembantu kemudian diberikan ke PPK SKPD untuk dilakukan verifikasi; dan (f) setelah mendapatkan verifikasi, Pengguna Anggaran menandatangani sebagai bentuk pengesahan.

\subsection{Pembahasan}

Sistem dan prosedur pengeluaran kas di Badan Perencanaan Penelitian dan Pengembangan Daerah Kota Manado dibandingkan dengan Permendagri Nomor 21 Tahun 2011 tentang Pengelolaan Keuangan Daerah adalah sebagai berikut:

1. Prosedur Surat Penyediaan Dana (SPD)

1). Kepala Badan sebagai Pengguna Anggaran menyusun dan menerbitkan DPA-SKPD, dan bertanggung jawab dalam mengontrol dan melaksanakan anggaran untuk kegiatan yang telah diarahkan. Prosedur pengeluaran kas pada Badan Perencanaan Penelitian dan Pengembangan Daerah Kota Manado telah sesuai dengan Permendagri Nomor 21 Tahun 2011 Pasal 10.

2). PPTK menyiapkan dokumen-dokumen Pengguna Anggaran kegiatan berupa nota atau bukti pembayaran dari pihak ke tiga dan bertanggung jawab atas beban pengeluaran anggaran kegiatan yang akan/telah dilaksanakan. Beban pengeluaran anggaran kegiatan tersebut menjadi dasar penyusunan surat permohonan pengajuan dana. Prosedur pengeluaran kas pada Badan Perencanaan Penelitian dan Pengembangan Daerah Kota Manado telah sesuai dengan Permendagri Nomor 21 Tahun 2011 Pasal 12 ayat (5) dan (6).

3). Bendahara pengeluaran dibantu oleh PPTK membuat surat permohonan pengajuan SPD yang dilampirkan bersama DPA-SKPD tahun anggaran yang bersangkutan kepada Pejabat Pengelola Keuangan Daerah (PPKD) selaku BUD atau kepada Kuasa BUD. Bendahara Pengeluaran menyerahkan Surat Permohonan Pengajuan SPD kepada BUD untuk diterbitkannya SPD yang ditandatangani oleh PPKD. Prosedur pengeluaran kas pada Badan Perencanaan Penelitian dan Pengembangan Daerah Kota Manado telah sesuai dengan Permendagri Nomor 21 Tahun 2011 Pasal 14 ayat (3) dan (5).

4). Surat Penyediaan Dana ditetapkan oleh PPKD selaku BUD dan disiapkan oleh Kuasa BUD yang ditunjuk sebagai dasar penerbitan SPP. Prosedur pengeluaran kas pada Badan Perencanaan Penelitian dan Pengembangan Daerah Kota Manado telah sesuai dengan Permendagri Nomor 21 Tahun 2011 Pasal 7 ayat (2) huruf f dan Pasal 8 ayat (2) huruf $b$.

5). Surat permohonan pengajuan SPD dilampirkan bersama DPA-SKPD sebagai dasar pelaksanaan anggaran SKPD. Prosedur pengeluaran kas pada Badan Perencanaan Penelitian dan Pengembangan Daerah Kota Manado sesuai dengan Permendagri No. 21 Tahun 2011 Pasal 124 ayat (4).

2. Prosedur Surat Permintaan Pembayaran (SPP)

1). Bendahara Pengeluaran menerima SPD dari BUD, selanjutnya berdasarkan SPD diterbitkan SPP-UP/GU/TU/LS beserta lampirannya. Prosedur penerbitan SPP Badan Perencanaan Penelitian dan Pengembangan Daerah Kota Manado telah sesuai dengan Permendagri Nomor 21 Tahun 2011 pada Pasal 198 ayat (2) dan (3).

2). Bendahara Pengeluaran menerbitkan dan mengajukan SPP berdasarkan SPD kepada PPK-SKPD untuk diperiksa kelengkapan dokumennya kemudian apabila dinyatakan lengkap maka diterbitkan SPM-UP/GU/TU/LS. Prosedur penerbitan SPP Badan Perencanaan Penelitian dan Pengembangan Daerah Kota Manado telah sesuai dengan Permendagri Nomor 21 Tahun 2011 pada Pasal 199.

3). Surat Permintaan Pembayaran (SPP) yang diterbitkan oleh Bendahara Pengeluaran terdiri dari SPP Uang Persediaan (SPP-UP), SPP Tambah Uang (SPP-TU), SPP Ganti 
Uang (SPP-GU), dan SPP Langsung (SPP-LS). Prosedur penerbitan SPP Badan Perencanaan Penelitian dan Pengembangan Daerah Kota Manado telah sesuai dengan Permendagri Nomor 21 Tahun 2011 pada Pasal 206.

4). Pejabat Penatausahaan Keuangan SKPD kemudian memeriksa kelengkapan SPP yang diterbitkan oleh bendahara pengeluaran, apabila dinyatakan tidak lengkap maka SPP dikembalikan untuk dilengkapi oleh Bendahara Pengeluaran. Prosedur penerbitan SPP Badan Perencanaan Penelitian dan Pengembangan Daerah Kota Manado telah sesuai dengan Permendagri Nomor 21 Tahun 2011 pada Pasal 210.

3. Prosedur Surat Perintah Membayar (SPM)

1). Apabila SPP dan dokumen lainnya dinyatakan lengkap maka PPK-SKPD menerbitkan SPM untuk ditandatangani oleh Ketua Badan sebagai Pengguna Anggaran, namun sebaliknya, jika dokumen lainnya dinyatakan tidak lengkap maka penerbitan SPM ditolak. Prosedur penerbitan SPM Badan Perencanaan Penelitian dan Pengembangan Daerah Kota Manado telah sesuai dengan Permendagri Nomor. 21 Tahun 2011 pada Pasal 211.

2). Penerbitan SPM paling lambat diterbitkan 2 hari sejak setelah dokumen SPP dinyatakan lengkap. Prosedur penerbitan SPM Badan Perencanaan Penelitian dan Pengembangan Daerah Kota Manado telah sesuai dengan Permendagri Nomor 21 Tahun 2011 pada Pasal 212 ayat (1).

3). Penolakan penerbitan SPM karena pengajuan SPP tidak lengkap, paling lama 1 hari sejak diterimanya SPP. Prosedur penerbitan SPM Badan Perencanaan Penelitian dan Pengembangan Daerah Kota Manado telah sesuai dengan Permendagri Nomor 21 Tahun 2011 pada Pasal 212 ayat (2).

4). Penerbitan SPM-UP/GU/TU/LS Badan Perencanaan Penelitian dan Pengembangan Daerah Kota Manado menggunakan buku register surat SPM-UP/GU/TU/LS. Apabila terjadi penolakan SPM maka dicatat pada buku register surat penolakan SPM. Prosedur penerbitan SPM Badan Perencanaan Penelitian dan Pengembangan Daerah Kota Manado telah sesuai dengan Permendagri Nomor 21 Tahun 2011 pada Pasal 214 ayat (1).

4. Prosedur Surat Perintah Pencairan Dana (SP2D)

1). Bendahara pengeluaran menyerahkan SPM kepada Kuasa BUD untuk diterbitkan Surat Perintah Pencairan Dana (SP2D). Prosedur penerbitan SP2D Badan Perencanaan Penelitian dan Pengembangan Daerah Kota Manado telah sesuai dengan Permendagri Nomor 21 Tahun 2011 pada Pasal 213.

2). Kuasa BUD meneliti kelengkapan dokumen SPM yang dilampirkan sekaligus dengan SPD, SPP dan dokumen atau bukti pengeluaran kas lainnya. Prosedur penerbitan SP2D BAPELITBANGDA telah sesuai dengan Permendagri Nomor 21 Tahun 2011 pada Pasal 216.

3). Kuasa BUD kemudian menerbitkan SP2D yang telah ditandatangani oleh PPKD paling lambat 2 hari. Prosedur penerbitan SP2D Badan Perencanaan Penelitian dan Pengembangan Daerah Kota Manado telah sesuai dengan Permendagri Nomor 21 Tahun 2011 pada Pasal 217 ayat (1).

4). Apabila SPM tidak lengkap dikembalikan pada Bendahara Pengeluaran untuk dilengkapi paling lambat 1 hari sejak pengajuan SPM dilakukan. Prosedur penerbitan SP2D Badan Perencanaan Penelitian dan Pengembangan Daerah Kota Manado telah sesuai dengan Permendagri Nomor 21 Tahun 2011 pada Pasal 217 ayat (2).

5). Apabila SP2D dalam bentuk UP/GU/TU maka diserahkan pada Ketua Badan (Pengguna Anggaran), apabila SP2D-LS maka kuasa BUD menyerahkan langsung kepada pihak ketiga. Prosedur penerbitan SP2D Badan Perencanaan Penelitian dan 
Pengembangan Daerah Kota Manado telah sesuai dengan Permendagri Nomor 21 Tahun 2011 pada Pasal 218.

5. Prosedur Surat Pertanggungjawaban (SPJ)

1). Pertanggungjawaban administrasi yang dilakukan oleh Bendahara Pengeluaran dilakukan paling lama 10 bulan berikutnya sejak dicairkan SP2D-UP/GU/TU kepada Pengguna Anggaran atau Kepala Badan. Prosedur pertanggungjawaban Badan Perencanaan Penelitian dan Pengembangan Daerah Kota Manado telah sesuai dengan Permendagri Nomor 21 Tahun 2011 pada Pasal 220.

2). Pertanggungjawaban administratif berupa SPJ dilampiri dengan: (1) Buku Kas Umum; (2) Laporan Penutupan Kas; dan (3) SPJ Bendahara Pengeluaran dan Pengeluaran Pembantu (merupakan gabungan dari laporan-laporan pertanggungjawaban UP/GU/TU pada bulan tersebut). Prosedur pertanggungjawaban Badan Perencanaan Penelitian dan Pengembangan Daerah Kota Manado telah sesuai dengan Permendagri Nomor 21 Tahun 2011 pada Pasal 220 ayat (4) dan (5).

3). Bendahara Pengeluaran menyiapkan laporan penutupan kas atau melakukan rekapitulasi jumlah-jumlah belanja dan item terkait lainnya berdasarkan BKU dan buku pembantu BKU lainnya serta khususnya buku pembantu rincian objek untuk mendapatkan nilai belanja per rincian obyek. Kemudian Bendahara Pengeluaran menggabungkan rekapitulasi tersebut dengan hasil yang ada di SPJ Bendahara Pengeluaran Pembantu. Berdasarkan rekapitulasi dan penggabungan itu, Bendahara Pengeluaran membuat SPJ atas pengelolaan uang yang menjadi tanggung jawabnya. Prosedur pertanggungjawaban Badan Perencanaan Penelitian dan Pengembangan Daerah Kota Manado telah sesuai dengan Permendagri Nomor 21 Tahun 2011 pada Pasal 220 dan Pasal 222

4). PPK-SKPD melakukan verifikasi atas Dokumen SPJ beserta BKU, Laporan Penutupan Kas dan SPJ Bendahara Pengeluaran Pembantu. Prosedur pertanggungjawaban Badan Perencanaan Penelitian dan Pengembangan Daerah Kota Manado telah sesuai dengan Permendagri Nomor 21 Tahun 2011 pada Pasal 221.

5). Pengguna Anggaran menandatangani sebagai bentuk pengesahan. Setelah Ketua Badan mengeluarkan surat pengesahan atas laporan pertanggungjawaban administrasi Bendahara Pengeluaran, selanjutnya Bendahara Pengeluaran menyampaikan laporan pertanggungjawaban fungsional kepada PPKD selaku BUD. Dokumen SPJ dan disertai dengan surat pengesahan laporan pertanggungjawaban dari Ketua Badan (Pengguna Anggaran) diserahkan ke BUD paling lambat 10 bulan berikutnya sejak dicairkannya SP2D-UP/GU/TU. Prosedur pertanggungjawaban Badan Perencanaan Penelitian dan Pengembangan Daerah Kota Manado telah sesuai dengan Permendagri Nomor 21 Tahun 2011 pada Pasal 220 ayat (10) dan (11).

\section{KESIMPULAN DAN SARAN}

\subsection{Kesimpulan}

Berdasarkan hasil penelitian dan pembahasan yang telah dilakukan di Badan Perencanaan Penelitian dan Pengembangan Daerah Kota Manado mengenai sistem dan prosedur pengeluaran kas maka dapat diambil kesimpulan bahwa Surat Penyediaan Dana (SPD), Surat Permintaan Pembayaran (SPP), Surat Perintah Membayar (SPM), Surat Perintah Pencairan Dana (SP2D), dan Surat Pertanggungjawaban (SPJ) pada Badan Perencanaan Penelitian dan Pengembangan Daerah Kota Manado telah sesuai dengan Peraturan Menteri dalam Negeri Nomor 21 Tahun 2011. Hal ini dapat disimpulkan bahwa Badan Perencanaan Penelitian dan Pengembangan Daerah Kota Manado sudah taat dalam menjalankan prosedur yang ada. 


\subsection{Saran}

Pada tahap pengajuan berkas dokumen, dianjurkan agar pegawai lebih teliti dalam mengajukan berkas apa saja yang dibutuhkan sehingga pada saat terjadi proses pengajuan tersebut tidak ada ketidaklengkapan berkas. Pegawai diberikan pembinaan/pelatihan sesuai dengan bidang pekerjaan atau pendidikannya, sehingga menjadi lebih paham mengenai tugas dan tanggung jawab. Hal ini dilakukan agar kesalahan atau kendala yang diakibatkan oleh human eror menjadi lebih berkurang atau tidak ada kesalahan yang terjadi.

\section{DAFTAR PUSTAKA}

Chandra, G., \& Adriana, D. (2015). Sistem informasi akuntansi konsep dan penerapan. Yogyakarta: CV. Andi Offset.

Horman, B. C., Sabijono, H., \& Afandi, D. (2018). Analisis pelaksanaan sistem dan prosedur penatausahaan pengeluaran kas di Kantor Kecamatan Malalayang Kota Manado. Jurnal Berkala Ilmiah Efisiensi. 18(3), $104-114$. https://ejournal.unsrat.ac.id/index.php/jbie/article/view/20872/20560.

Krismiaji. (2015). Sistem informasi akuntansi. Yogyakarta: UPP STIM YKPN.

Mulyadi. (2016). Sistem akuntansi. Edisi keempat. Jakarta: Salemba Empat.

Ointu, M. R., \& Budiarso, N. (2016). Evaluasi pelaksanaan sistem dan prosedur pengeluaran kas uang persediaan pada DPPKAD Kab. Bolaang Mongondow Selatan. Jurnal EMBA Jurnal Riset Ekonomi Manajemen dan Akuntansi, 4(3). 156-164. https://ejournal.unsrat.ac.id/index.php/emba/article/view/13662

Peraturan Menteri Dalam Negeri Nomor 21 Tahun 2011 Tentang Perubahan Kedua Atas Peraturan Menteri Dalam Negeri Nomor 13 tahun 2006 Tentang Pedoman Pengelolaan Keuangan Daerah.

Peraturan Pemerintah Nomor 24 Tahun 2005 Tentang Standar Akuntansi Pemerintahan.

Peraturan Pemerintah Nomor 12 Tahun 2019 Tentang Pengelolaan Keuangan Daerah.

Pontoh, W. (2013). Akuntansi konsep dan aplikasi. Jakarta: Halaman Moeka.

Romney, M. B., \& Steinbart, P. J. (2015). Sistem informasi akuntansi. Edisi 13.Jakarta: Salemba Empat.

Sujarweni, V. W. (2015). Akuntansi sektor publik: Teori, konsep aplikasi. Yogyakarta: Pustaka Baru Press.

Susanto, A. (2018). Sistem informasi akuntansi. Edisi Perdana. Cetakan pertama. Bandung: Lingga Jaya.

Sutabri, T. (2012). Analisis sistem informasi. Yogyakarta: Andi

Tenda, S. H., Ilat, V., \& Walandouw, S. K. (2015). Analisis sistem informasi akuntansi pengeluaran kas pada Biro Umum Sekretariat Daerah Provinsi Sulawesi Utara. Jurnal Berkala Ilmiah Efesiens, https://ejournal.unsrat.ac.id/index.php/jbie/article/view/10507/10095

Harrison, W. T., Horngren, C. T., Thomas, C. W., \& Suwardy, T. (2012). Akuntansi keuangan IFRS. Edisi Kedelapan. Jilid 1. Jakarta: Erlangga.

Wonggo, P. M., Afandi, D., \& Suwetja, I. G. (2017). Analisis sistem penatausahaan belanja langsung di Pemerintah Kabupaten Minahasa Selatan (Studi kasus pada Dinas Sosial Tenaga Kerja dan Transmigrasi). Jurnal Riset Akuntansi Going Concern, 12(2), 157166. https://doi.org/10.32400/gc.12.2.17446.2017 